\title{
On the Structure of the Heart in Fishes of the Genus Gadus.
} By M. Jourdain.

In 1858 Professor Hyrtl of Vienna published an interesting memoir on the absence of blood-vessels in the hearts of certain Vertebrata. He announced that the heart in the Batrachia is completely deprived of vessels-a peculiarity previously unknown, and the reality of which, we may say in passing, we have ascertained in the Batrachia of this country. The aortic bulb alone possesses some very delicate vascular branches, comparable to the vasa vasorum, of which M. Hyrtl indicated the origin, course, and termination with the rigorous exactitude characteristic of that anatomist, a recognzied master in the art of injection.

The heart in the bony fishes presents a state intermediate between the heart without vessels of the Batrachia and the vascular heart of the Mammalia and Birds, - that is to say, that only one-half of the thickness of the ventricular wall, the outer stratum, receives branches of the arterial system, and that the other half is completely deprived of then. The heart in the osseous fishes might therefore be designated a semivascular heart. The central organ of the circulation presents this plan of construction in the fishes of our coasts. The most penetrating fine injections never implicate more than the outer layer of the ventricle, the compact structure of which approaches what we are accustomed to see in the heart of the Mammalia and Birds. The inner layer, in which, we repeat, the most minute examination fails to detect the least trace of vascularity, presents, on the contrary, a soft and spongy texture, and separates readily from the outer layer of dense tissue - a peculiarity alluded to by Cuvier, Döllinger, and Rathke, who did not, however, understand its significance.

The Gadi present an exception which the mode of circulation 6 fishes renders worthy of remark. Like that of the Batrachia, the heart of the Gadi is destitute of the vascular element. Fine injections driven in through the arteries so as to return by the veins, never penetrate into the walls of the ventricle, nor into those of the auricle. The aortic bulb alone possesses some very slender branches; but these never pass the scissure which separates this last cardiac chamber from the preceding one. The arterioles are furnished by the hyoidian artery, which is dependent upon the first two epibranchials; the venules open into the hyoidian veins, which in their turn are tributaries of the common venous sinus. With this absence of vessels corresponds a peculiar structure of the ventricular walls, very analogous to that observed in the Batrachia. The muscular fibres, instead of constituting by their apposition a dense and compact tissue, form bundles and trabeculæ, which divide and interlace in such a manner as to give origin to an areolar and spongy mass. It is in the irregular passages and lacunar spaces thus produced that the venous blood diffuses itself at the moment of the ventricular diastole. At this moment the blood permeates the walls of the ventriele like a sponge, and it is pressed out again by the movement of systole which succeeds.

Ann.\& Mag. N. Hist. Ser. 3. Vol. xix. 
The heart in the Gadi, like that of osseous fishes in general, being a venous heart, and, on the other hand, its ventricle and auricle being always deprived of vessels with red blood, it follows necessarily that the venous blood alone serves for the nutrition of muscular fibre, and maintains the contractility of the latter. It is by the repeated conflict of the venous blood and the muscular fibre that is produced the double movement of assimilation and decomposition which constitutes nutrition. We are convinced that the venous blood issuing from the heart would furnish on analysis a somewhat higher proportion of carbonic acid than that which enters the auricle, since the blood driven into the branchial artery must contain in addition the acid formed by the muscles of the auricle and ventricle in consequence of their contraction.-Comptes Rendus, January 28th, 1867, pp. 192-194.

On a new Specimen of Telerpeton Elginense.

By Prof. T. H. Huxley, LL.D., F.R.S., V.P.G.S.

The specimen which was described in this paper had been broken into five pieces, exhibiting hollow casts of most of the bones of Telerpeton Elginense. It is the property of Mr. James Grant of Lossiemouth, and came from the reptiliferous beds of that locality, along with some highly interesting fragments of Stagonolepis and Hyperodapedon. The casts described by the author consisted of impressions of the bones of the skull, together with the lower jaw and the teeth, of most of the vertebræ and ribs, of the greater portions of the pelvic and scapular arches, and of representatives of must of the bones of the fore and hind limbs; and it was stated that the characters of all these portions of the skeleton indicated decidedly Lacertilian affinities.

In describing these remains, Professor Huxley discussed especially the biconcave character of the vertebræ, the mode of implantation of the teeth (which he believed to be Acrodont, and not Thecodont), and the anomalous structure of the fifth digit of the hind foot (which presents only two phalanges, a proximal and a terminal) - a structure which differs from that of all known Lacertilian Reptiles, whether recent or fossil. His researches had led him to conclude that the animal is one of the Reptilia, and is devoid of the slightest indication of affinity with the Amphibia. In all its characters it is decidedly Saurian, and accords with the suborder Kionocrania of the true Lacertilia; but the author had not been able to make sure that it possessed a columella. He also remarked that the possession by Telerpeton Elginense of vertebræ with concave articular faces does not interfere with this view, as, although most recent Lacertilia have concavo-convex vertebræ, biconcave vertebræ much more deeply excavated than those of $T$. Elginense are met with among the existing Geckos.

Professor Huxley in conclusion drew attention to the interesting fact that Telerpeton presents not a single character approximating it towards the type of the Permian Proterosauria, or the Triassic 


\section{$2 \mathrm{BHL}$ Biodiversity Heritage Library}

Jourdain, S. 1867. "On the structure of the heart in fishes of the genus Gadus." The Annals and magazine of natural history; zoology, botany, and geology 19, 225-226.

View This Item Online: https://www.biodiversitylibrary.org/item/72153

Permalink: https://www.biodiversitylibrary.org/partpdf/61010

\section{Holding Institution}

University of Toronto - Gerstein Science Information Centre

\section{Sponsored by}

University of Toronto

\section{Copyright \& Reuse}

Copyright Status: NOT_IN_COPYRIGHT

This document was created from content at the Biodiversity Heritage Library, the world's largest open access digital library for biodiversity literature and archives. Visit BHL at https://www.biodiversitylibrary.org. 